\title{
バットグリップ位置の変化が野球の打撃タイミングと 床反力および筋活動に与える影響
}

\author{
太田 洋一1) 中本 浩揮2)
}

Yoichi Ohta ${ }^{1}$ and Hiroki Nakamoto 2 : Effects of changes in bat grip position on baseball bat swing timing, ground reaction force, and muscle activation characteristics. Japan J. Phys. Educ. Hlth. Sport Sci. 60: 527-537, December, 2015

\begin{abstract}
This study aimed to clarify the effects of changing to a short bat grip position from the long bat grip position on baseball bat swing timing, peak ground reaction force with the front leg, and activation of the upper and lower limb muscles.

Nine male college baseball players participated in this study. By using a batting simulator, the coincident timing task was to swing the bat coincidentally with the arrival timing of a moving target by using the long or short bat grip position. The batter performed 10 sets of 4 swings for a total of 40 swings for the coincident timing task. During the four swings, the batter swung the bat by using the long grip position in the first, second, and fourth swings. Only in the third swing did the batter use the short grip position. The ground reaction force with the front leg was measured, and electromyograms of the upper and lower limb muscles were obtained during the coincident timing task.

Our results indicated no significant differences in absolute and variable timing errors between the long and short bat grip positions. In contrast, the constant timing error was significantly increased with the short bat grip position. Moreover, the time to peak ground reaction force and time to peak muscle activation of both the upper and lower limb muscles were significantly delayed when the short bat grip position was employed. Significant positive relationships were observed between the constant timing error and time to peak ground reaction force, which showed differences between the second and third swings. No significant difference in swing time was observed between the long and short bat grip positions.

These findings indicate that changing to the short bat grip position from the long bat grip position will not improve the batter's swing timing. Furthermore, changing to the short bat grip position could delay the batter's swing timing, probably because the change causes a delay in swing preparation.
\end{abstract}

Key words : coincident timing task, accuracy, swing time, choke-up grip, electromyography キーワード : 一致タイミング課題, 正確性, スイング時間, 短いバット, 筋電図

\section{1. 緒言}

野球の試合では，投球速度の大きい投手に対し て打者が振り遅れた場合に「バットを短く持て」
とコーチや監督が指示することがある.「バット を短く持つ」とは, 通常よりもバットヘッドに近 い位置（グリップエンドから遠い位置）を握るこ とであり,グリップ位置からバッドヘッドをでの 距離を短くするバットの把持方法である．このよ

1. Faculty of Health and Medical Sciences, Department of Sports and Health Sciences, Aichi Shukutoku University

2-9 Katahira, Nagakute, Aichi 480-1197

2. Department of Physical Education, Sports Humanities and Applied Social Science, National Institute of Fitness and Sports in Kanoya

1 Shiromizu, Kanoya, Kagoshima 891-2393

Corresponding author t_uzura76@live.jp 
うなコーチや監督からの指示は，バットを短く持 つことで，スイング時間の減少やスイング速度の 増加, 打撃タイミングやバットコントロールの向 上，さらに，バットを軽く感じたり，集中力を高 めたりする効果があると考えられているためであ る (DeRenne and Blitzbau, 1990). 先行研究で は，バットを短く持つことでスイング動作の前脚 が離地した時間から接地するまでの時間（ストラ イド時間）が減少し，トータルのスイング時間 （前足離地からインパクトまでの時間）が短くな ると報告されている（DeRenne et al., 2010 ; Escamilla et al., 2009). しかし, バットを短く 持っても, 前脚接地後のスイング時間は有意に変 化しないことや（Escamilla et al., 2009 ; 川端・ 伊藤，2012；島田ほか，2008)，バットスイング 速度は低下（DeRenne and Blitzbau, 1990； DeRenne et al., 2010 ; Escamilla et al., 2009 ; 川 端・伊藤, 2012 ; 渡邊ほか，2006）または変化 しない（島田ほか，2008）ことが報告されてい る.したがって，バットを短く持つことによるス イング時間への影響は限定的なものであると考え られ，監督や選手が考える効果と実際のデータは 必ずしも一致するものとは言えない。スポーツ競 技に打いては，競技現場（選手やコーチ）の認識 と実際のデータとの相違を明らかにする事は重要 なことである.

バイオメカニクス的な先行研究からバットを短 く持つことによるスイング動作への影響は明確に されつつあるが，打撃のタイミングといった知 覚一運動制御に与える影響は明らかにされていな い.バットでボールを正確に打撃するためには, 投げられたボールの到達に合わせて，タイミング よくスイング動作を実行しなければならない。そ の為, 時間的な打撃タイミング能力は, 打撃パフ オーマンスを決定する 1 つ要因と考えられ る.バットを短く持つことで打撃のタイミングが 向上すると示唆されているが (DeRenne and Blitzbau, 1990), 詳細な研究は行われていない. グリップ位置の違いが打撃タイミングへ与える影 響を明らかにする事は打撃指導に打ける有用な知 見となると考えられる.
先行研究では, 通常のグリップ位置と通常より も短いグリップ位置の打撃をそれぞれ10回ずつ 実施するなど別々のブロックで打撃を行わせてい るが (e.g., DeRenne et al., 2010 ; Escamilla et al., 2009 ; 川端·伊藤, 2012), 野球の現場で は, 打者が 1 打席中にバットグリップ位置を変 化させることも少なくない，そこで，本研究で は，バットを短く持ち替えるまたは長く持ち替え る状況を想定した実験条件を採用した。 また，本 研究では, バットを短く持ち替えた場合, 打撃タ イミングの時間的な正確性は向上しない, もしく は低下すると仮説を立てた。なぜなら，バットを 短く持った場合の打者の認識と実際の打撃動作の データに違いが認められることや, グリップ位置 に関わらずヒットとして認められる打球を打つ確 率は一定であると報告されているからである (DeRenne et al., 2010).

打撃タイミングと床反力との関係を検討した研 究からは, 打撃タイミングは前脚が地面を踏みし めるタイミングや地面に大きな力を加えたタイミ ングと密接な関係が認められると報告されている (Katsumata, 2007). また, 野球のスイング動作 は様々な筋の活動によって実行され（Kitzman, 1964 ; Shaffer et al., 1993), 筋活動の調節は打撃 タイミングに関係する要因であると報告されてい る（Ohta et al., 2014 ; Ohta et al., 2015)．したが って, 打撃のタイミングを検討する場合, 単に標 的とのインパクトタイミングだけでなく, 様々な 動作や力発揮のタイミングさらに筋活動のタイミ ングから検討を行う必要があると考えられる。こ れらのことから, 本研究では, グリップ位置の変 化が打撃のタイミングに与える影響を，インパク トタイミングだけでなく, 前脚の踏みしめタイミ ング（床反力）抢よび上下肢の筋活動のタイミン グから明らかにすることを目的とした。

\section{2. 方 法}

\section{1. 被検者}

大学硬式野球部の野手 9 名 (年齢20.7 \pm 1.3 歳, 身長 $171.8 \pm 4.8 \mathrm{~cm}$, 体重 $70.4 \pm 8.1 \mathrm{~kg}$ ）を対象 
とした. 右打ち 5 名, 左打ち 4 名であった。被 検者に対し実験目的と方法の説明を行い，内容を 理解のうえ実験参加の承諾を得た。本実験は所属 研究機関の研究倫理委員会の了承を得たものであ る. 実験準備に先立って, バットを短く持つ事に よるスイングへの主観的な印象を質問した．質問 は「バットを短く持った場合にスイングに対して 感じることはありますか?」とし，自由回答とし た。この質問は，被検者のバットを短く持つこと に対する印象を確認するためだけに用いられた。

\section{2. 実験課題}

本研究では, 実打ではなく打撃シミュレーター を使用した。その理由は，提示課題の時間的な再 現性と多数の試技による定量的な分析を優先した ためである．実際にボールを打撃する実験環境で は，時間的条件（投球時間や投球速度）が一致し た試技を多数測定することは困難であり，定量的 な評価を行うことが難しい。したがって，ターゲ ットの開始から到達までの時間的条件を再現する ことが可能な打撃シミュレーターを用いて実験を 行った.

被検者は利き打席で木製バット（アディダス社 製：DDN87，長さ $84 \mathrm{~cm}$ ，重さ $780 \mathrm{~g}$ ）を握り, 打撃シミュレーターと平行になるよう立位姿勢を とり, 開始点から直線移動してくる移動指標が到 達点に到達する瞬間に合わせてバットをスイング する一致タイミング課題を行った（図 1). 打撃 ポイントは移動指標の到達点に設置された光電管
装置上とし，前脚が床に設置されたフォースプ レート（KISTLER 社製：Type9287C）上に乗 るようにスイングを行わせた（図 1 )。標的の移 動開始から到達までの刺激提示時間は先行研究を 参考に $500 \mathrm{~ms}$ とした (Nakamoto et al., 2012 ; Ohta et al., 2014 ; Ohta et al., 2015).この時間 は，実際の野球の投球速度では約 $132.8 \mathrm{~km} / \mathrm{h}$ に 相当するものである. 被検者には標的の到達に合 わせてスイングが出来る様になるまで練習を行わ せ，練習試技中にはスイング毎にタイミング誤差 を口頭でフィードバックした．練習試技ではバッ トの最もグリップエンドに近い位置を握らせて行 わせた。バットを短く持ち替えた際の打撃タイミ ングへの影響についてテスト試技前に学習しない ように，バットを短く持った状態で一致タイミン グ課題の練習試技は行わせなかった。

次に，4 スイング 1 セットのテスト試行を $10 セ ~$ ット行わせた。 バットは被検者全員が同一の木製 バットを使用した．各セット $1 ， 2 ， 4$ スイング目 は最もグリップエンドに近い位置を握るロンググ リップポシシションとし，3 スイング目のみロング グリップポジションから拳一握り分短い位置を握 るショートグリップポシシションに持ちかえてスイ ングを行わせた。グリップ位置は先行研究の条件 を参考とした（川端・伊藤，2012）。被検者には できるだけ強くスイングするように指示した． 1 セット中のスイング間のインターバルは約 10 秒 とし，セット間のインターバルは約 3-5 分とし た。テスト試技は全て同一の刺激提示条件（500

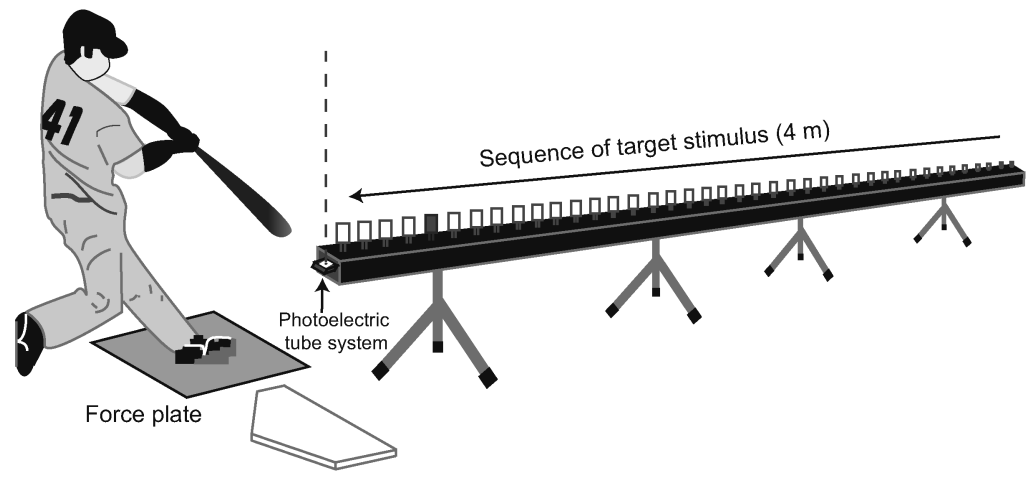

Figure 1 Representation of experimental set-up. 
ms）で行われた.

テスト試技では，被検者に 1 スイング毎，ス イングタイミングの早遅についての主観を 5 段 階評価（5：明らかに早い，4：どちらかと言え ば早い，3：ちょうどいい，2 どちらかと言えば 遅い，1：明らかに遅い）で答えさせ，その後口 頭でタイミング誤差の実数值のフィードバックを した。 また，バットのグリップを持ち替える 3,4 スイング目には，スイング終了後に前のスイング と比較したバットの重さに関する主観（5：明ら かに軽い 4 ：どちらかといえば軽い 3 : 変わら ない $2:$ どちらかといえば重い 1 : 明らかに重 い）とスイングスピードに関する主観（5：明ら かに速い 4 ：どちらかといえば速い 3 : 変わら ない $2:$ :゙ちらかといえば遅い 1 : 明らかに遅 い）も 5 段階評価で答えさせた.

\section{3. 実験装置}

\subsection{1. 打撃シミュレーター}

200個の赤色発光ダイオード（LED）を $2 \mathrm{~cm}$ 間隔で配置した長さ $4 \mathrm{~m}$ のレール（アプライド オーフィス社製：AO-1M）を使用して作成した 打撃シミュレーターを用いた。打撃シミュレー ターは, 3 秒間の予告刺激の点灯後, 移動指標と なる光が開始点から到達点まで経時点灯し, 移動 指標が被検者に向かってくるように見える装置で あり, 先行研究で用いられているものである (Nakamoto et al., 2012 ; Ohta et al., 2014 ; Ohta et al., 2015). 打撃シミュレーターの到達点に設 置された光電管装置（アプライドオーフィス社 製： $\mathrm{AO}-2 \mathrm{CH} ）$ 上をバットが通過した時間をイ ンパクト時間として計測した。 野球規則に則った 打席を作成し, 到達点の光電管装置がホームベー ス上の先端中心に来るように配置した. 打撃シミ ュレーターから標的移動開始時間, 標的到達時間 およびインパクト時間を 2 台の $\mathrm{A} / \mathrm{D}$ 变換器 （AD Instrument 社製：Power-Lab 16sp）を用い てサンプリング周波数 $1 \mathrm{kHz}$ で 2 台のパソコン 上のソフトウェア $(\mathrm{AD}$ Instrument 社製 : Chart 7.3.7）に保存し, 筋電図抢よびフォースプレー トのデータとの同期を行った.

\subsection{2. 筋電図}

打者の投手側（前脚側 : 右打者は左, 左打者は 右) の上腕三頭筋 $(\mathrm{F}-\mathrm{TB})$, 大腿二頭筋 $(\mathrm{F}-\mathrm{BF})$, 前脛骨筋 $(\mathrm{F}-\mathrm{TA})$, 外側広筋 $(\mathrm{F}-\mathrm{VL})$, 腓腹筋 内側頭（F-MG）抢よび捕手側（後ろ脚）の腓腹 筋内側頭 $(\mathrm{B}-\mathrm{MG})$ から筋電図を導出した. 上肢 筋はスイング動作中に顕著な活動を示す上腕三頭 筋を選択した（Ohta et al., 2014）．前脚の動作タ イミングおよび前脚の外側広筋の筋活動が打撃タ イミングに関連すると報告されていることから (Katsumata, 2007 ; Ohta et al., 2015)，前脚の膝 関節および足関節の屈伸に関わる主要な筋である 外側広筋, 腓腹筋内側頭, 大腿二頭筋および前脛 骨筋を測定した。後ろ脚は予備実験でスイング動 作中に顕著な活動が認められた腓腹筋内側頭を測 定した。筋電図の測定には, 多用途テレメーター 筋電計システム（バイオログ社製：DL-5000型 システム）を使用した．筋電図信号はサンプリン グ周波数 $1 \mathrm{kHz}$ で $\mathrm{A} / \mathrm{D}$ 変換器 ( $\mathrm{AD}$ Instrument 社製：Power-Lab 16sp）を通してパソコン上の ソフトウェア $(\mathrm{AD}$ Instrument 社製：Chart 7.3.7) に保存し，打撃シミュレーターからのデータと同 期を行った。筋電図信号はソフトウェア（AD Instrument 社製：Chart 7.3.7）を用いて全波整 流化しバンドパスフィルター $(15-250 \mathrm{~Hz})$ で 処理した後, 積分 (time constant, $50 \mathrm{~ms}$ ) し分 析に用いた。

\subsection{3. 床反力}

床に設置されたフォースプレート（KISTLER 社製：Type9287C）を用いてスイング動作中の 前脚の床反力を測定した。床反力データは $\mathrm{A} / \mathrm{D}$ 変換器 $(\mathrm{AD}$ Instrument 社製: Power-Lab 16sp) を用いてサンプリング周波数 $1 \mathrm{kHz}$ でパソコン 上のソフトウェア $(\mathrm{AD}$ Instrument 社製 : Chart 7.3.7）に保存し打撃シミュレーターからのデー タと同期した.

\section{4. 分析項目}

標的提示時間（500 ms） と標的移動開始から インパクトまでの時間の差からタイミング誤差を 算出した，標的の到達よりも早いタイミングでス 
イングを行った場合はー（マイナス）の值とし， 標的の到達よりも遅いタイミングでスイングを行 った場合は+（プラス）の值とした. 打撃タイミ ングの偏向・正確性・変動性を検討するために,

CE (Constant Error : 誤差の偏向とその大きさ を表す誤差), AE (Absolute Error : 移動指標到 達からの絶対誤差) および VE (Variable Error : 個人内の変動誤差）の 3 つ指標を算出した. $\mathrm{CE}, \mathrm{AE}, \mathrm{VE}$ は下の数式から算出した (Schmidt and Lee, 2011).

$$
\begin{aligned}
C E & =\left[\Sigma\left(X_{i}-T\right) / N\right] \\
A E & =\left[\Sigma\left(\left|X_{i}-T\right|\right) / N\right] \\
V E & =\sqrt{\left[\Sigma\left(X_{i}-M\right)^{2} / N\right]}
\end{aligned}
$$

ここで, $i=$ 試技, $X i=i$ 回目の試技の標的開始か らインパクトまでの時間, $T=$ 標的提示時間, $N$ =試技数, $M=N$ 試技の標的開始からインパク 卜までの時間の平均である。

筋電図は, 積分筋電図に変換し標的の移動開始 からインパクトまでの各筋の最大值および最大值 発揮時間を算出した。最大值発揮時間は標的移動 開始からの時間とした，筋電図の最大值は等尺性 筋活動時の最大值を用いて標準化した（\% maximal voluntary contraction: \% MVC).

床反力データからは垂直成分 $(\mathrm{Fz})$ の力が連 続的に最大值まで増加を開始する時間（床反力増 加開始時間), 床反力最大值発揮時間および床反 力最大值を計測した. 床反力増加開始時間および 床反力最大值発揮時間は標的移動開始からの時間 とした. さらに, 床反力最大值発揮時間からイン パクト時間までをスイング時間として算出した (川端・伊藤, 2012).

\section{5. データ分析}

各データはスイング毎 $(1,2,3,4$ スイング $)$ の 10セットの平均值を算出した。この際, 各被検 者内において， $\mathrm{CE}$ の平均值に対して $\pm 2 \mathrm{SD}$ の範 囲から外れたデータは被検者内の平均から除外し た。スイング間の違いは，対応のある 1 要因分 散分析を行い，主効果が認められた場合は，多重 比較（Bonferroni）を用いて分析を行った． 3 ス イング目抢よび 4 スイング目のバットの重さと
速さに関する主観の傾向は 1 標本の $\mathrm{t}$ 検定（検定 值＝3）を用いて分析した. CE および床反力最 大值発揮時間の 2 スイング目と 3 スイング目の 差を算出し, 両者の関係をPearsonの積率相関 係数を用いて分析した. 効果量として偏イーター 二乗 $\left(\eta_{\mathrm{p}}{ }^{2}\right)$ を算出した。統計処理にはSPSSソ フトウェア(IBM 社製：IBM SPSS Statistics 22) を用いた。

\section{3. 結 果}

\section{1. 主観}

スイングタイミングの早遅についての主観は， 1 スイング目 $(2.84 \pm 0.26), 2$ スイング目 $(2.93$ $\pm 0.36) ， 3$ スイング目 $(2.84 \pm 0.28) ， 4$ スイン グ目 $(2.66 \pm 0.35)$ であった. スイング条件で 1 要因分散分析を行った結果, 有意な主効果は認め られなかった $\left(\mathrm{F}(3,24)=1.813, \mathrm{p}=0.172, \eta_{\mathrm{p}}{ }^{2}=\right.$ 0.185). バットのグリップを持ち替えた 3,4 スイ ング目の前スイング（2, 3 スイング目）と比較し たバットの重さに関する主観は，3 スイング目 $3.69 \pm 0.63(\mathrm{t}(8)=3.246, \mathrm{p}=0.012), 4$ スイング 目2.34 $0.46 （ \mathrm{t}(8)=-4.309, \mathrm{p}=0.003)$ であっ た。これは，バットを短く持ち替えた 3 スイン グ目は 2 スイング目と比較して有意にバットが 軽かったと感じて抢り，長く持ち直した 4 スイ ング目は 3 スイング目と比較して，有意にバッ トが重かったと感じていたことを示している。ま た， 3, 4 スイング目のバットの速さに関する主観 は, 3 スイング目 $3.26 \pm 0.45(\mathrm{t}(8)=1.755, \mathrm{p}=$ $0.117) ， 4$ スイング目 $2.78 \pm 0.38(\mathrm{t}(8)=$ $-1.743, \mathrm{p}=0.120)$ であり, 前のスイングに対し て有意な違いは認められなかった。

\section{2. タイミング誤差}

各スイングの CE について，1要因分散分析を 行った結果, スイング条件に有意な主効果が認め られた $\left(\mathrm{F}(3,24)=3.615, \mathrm{p}=0.028, \eta_{\mathrm{p}}{ }^{2}=\right.$ $0.311)$. 多重比較の結果，3 スイング目は 2 スイ ング目よりも有意に高值を示した $(\mathrm{p}=0.024$, 図 2)。この結果は，3 スイング目にバットを短く持 


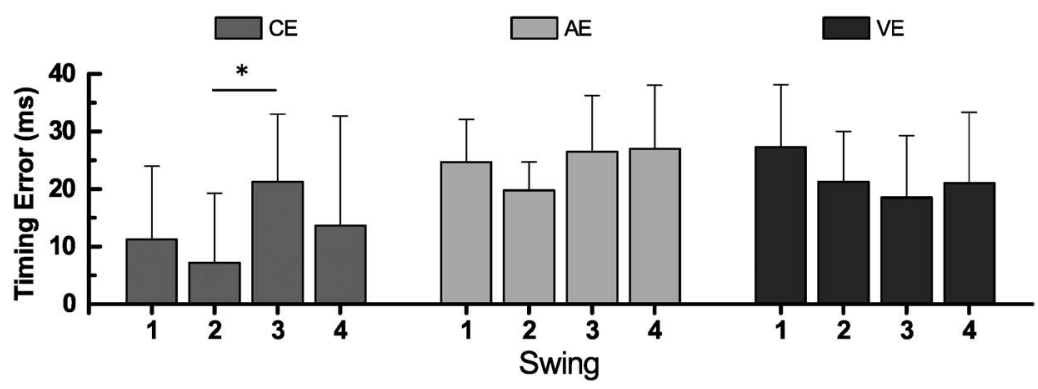

Figure 2 Differences in constant error $(\mathrm{CE})$, absolute error (AE), and variable error (VE) between the 4 swings. ${ }^{*} \mathrm{p}<0.05$
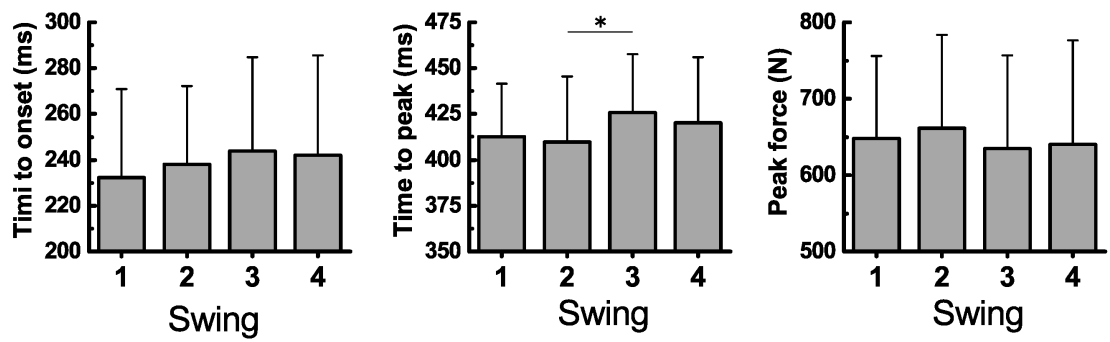

Figure 3 Differences in time to onset (left) and time to peak (middle) from target start and peak ground reaction force (right) between the 4 swings. ${ }^{*} \mathrm{p}<0.05$

ち替えることによって，ターゲットの到達よりも 遅れてスイングを行う（振り遅れる）傾向が強く

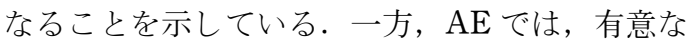
主効果は認められなかった $(\mathrm{F}(3,24)=1.485, \mathrm{p}$ $=0.244, \eta_{\mathrm{p}}{ }^{2}=0.157$, 図 2$)$. また, VEにおいて も有意な主効果は認められなかった $(\mathrm{F}(3,24)=$ $1.544, \mathrm{p}=0.229, \eta_{\mathrm{p}}^{2}=0.162$, 図 2).

\section{3. 床反力}

床反力増加開始時間について，スイング条件で 有意な主効果は認められなかった $(\mathrm{F}(3,24)=$ $0.643, \mathrm{p}=0.595, \eta_{\mathrm{p}}{ }^{2}=0.074$, 図 3 左). 最大值発 揮時間は, スイング条件に有意な主効果が認めら れ $\left(\mathrm{F}(3,24)=5.090, \mathrm{p}=0.007, \eta_{\mathrm{p}}{ }^{2}=0.389\right)$ ，多 重比較の結果， 3 スイング目は 2 スイング目より も有意に高值を示した（ $\mathrm{p}=0.027$, 図 3 中 $)$.こ の結果は，バットを短く持ち替えることによっ て，スイング中の前脚の床反力最大值発揮時間が 遅延したことを示している. 床反力最大值は，ス イング条件で有意な主効果は認められなかった

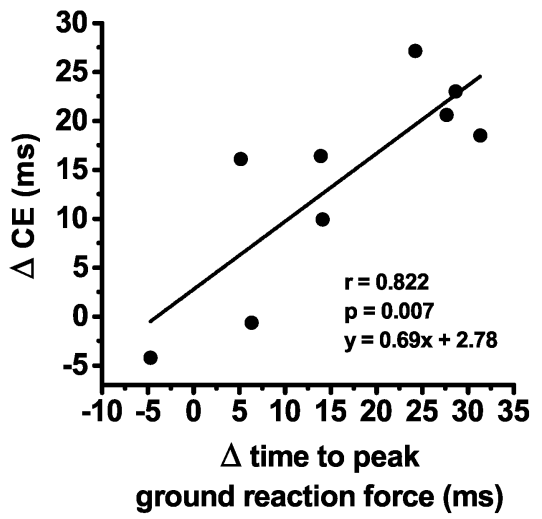

Figure 4 Relationship between $\Delta$ constant error (CE) and $\Delta$ time to peak ground reaction force, which showed differences between the second and third swings.

$\left(\mathrm{F}(3,24)=1.497, \mathrm{p}=0.241, \eta_{\mathrm{p}}{ }^{2}=0.158\right.$, 図 3 右). 2 スイング目と 3 スイング目の $\mathrm{CE}$ の差と 床反力最大值発揮時間の差との間には有意な被検 者間の正の相関関係が認められた $(\mathrm{r}=0.822, \mathrm{p}$ $=0.007$, 図 4). 


\section{4. スイング時間}

スイング時間について，スイング条件で有意な 主効果は認められなかった $(\mathrm{F}(3,24)=2.645, \mathrm{p}$ $=0.072, \eta_{\mathrm{p}}^{2}=0.248$, 図 5).

\section{5. 筋電図}

筋電図の最大值発揮時間について, F-TA， F$\mathrm{MG}, \mathrm{F}-\mathrm{BF}, \mathrm{F}-\mathrm{TB}$ では，スイング条件に有意な 主効果は認められなかった $(\mathrm{F}(3,24)=1.097, \mathrm{p}$

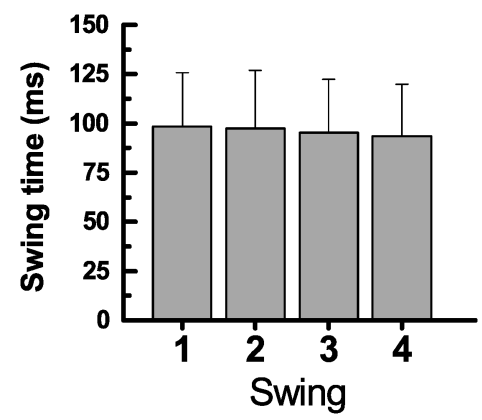

Figure 5 Difference in swing time between the 4 swings. $\left.=0.369, \quad \eta_{\mathrm{p}}^{2}=0.121\right), \quad(\mathrm{F}(3,24)=0.312, \quad \mathrm{p}=$ $\left.0.816, \eta_{\mathrm{p}}^{2}=0.038\right),(\mathrm{F}(3,24)=1.730, \mathrm{p}=0.188$, $\left.\eta_{\mathrm{p}}{ }^{2}=0.178\right), \quad\left(\mathrm{F}(3,24)=2.876, \mathrm{p}=0.057, \eta_{\mathrm{p}}{ }^{2}=\right.$ 0.264, 図 6). 一方, B-MG および F-VL の最大 值発揮時間では，スイング条件に有意な主効果が 認められた $\left(\mathrm{F}(3,24)=3.874, \mathrm{p}=0.022, \quad \eta_{\mathrm{p}}{ }^{2}=\right.$ $0.326), \quad\left(\mathrm{F}(3,24)=3.167, \quad \mathrm{p}=0.043, \quad \eta_{\mathrm{p}}{ }^{2}=\right.$ 0.284, 図 6). 多重比較の結果, B-MG では, 3 スイング目は1スイング目との間に有意な違い が認められた $(\mathrm{p}=0.029)$. また， F-VLでは，3 スイング目と 2 スイング目との間に有意な違い が認められた（p=0.040, 図 6).

筋電図の最大值について，F-TA，F-MG，F$\mathrm{BF}, \mathrm{F}-\mathrm{TB}$ では，スイング条件に有意な主効果は 認められなかった $(\mathrm{F}(3,24)=2.070, \mathrm{p}=0.131$, $\left.\eta_{\mathrm{p}}{ }^{2}=0.206\right), \quad\left(\mathrm{F}(3,24)=2.667, \mathrm{p}=0.071, \eta_{\mathrm{p}}{ }^{2}=\right.$ $0.250),\left(\mathrm{F}(3,24)=2.321, \mathrm{p}=0.101, \eta_{\mathrm{p}}{ }^{2}=0.225\right)$, $\left(\mathrm{F}(3,24)=2.422, \mathrm{p}=0.091, \eta_{\mathrm{p}}^{2}=0.232\right.$, 図 7).

一方, B-MG 抢よび F-VLでは, スイング条件 に有意な主効果が認められたが $(\mathrm{F}(3,24)=$ $\left.3.338, \mathrm{p}=0.036, \eta_{\mathrm{p}}^{2}=0.294\right),(\mathrm{F}(3,24)=3.921$,
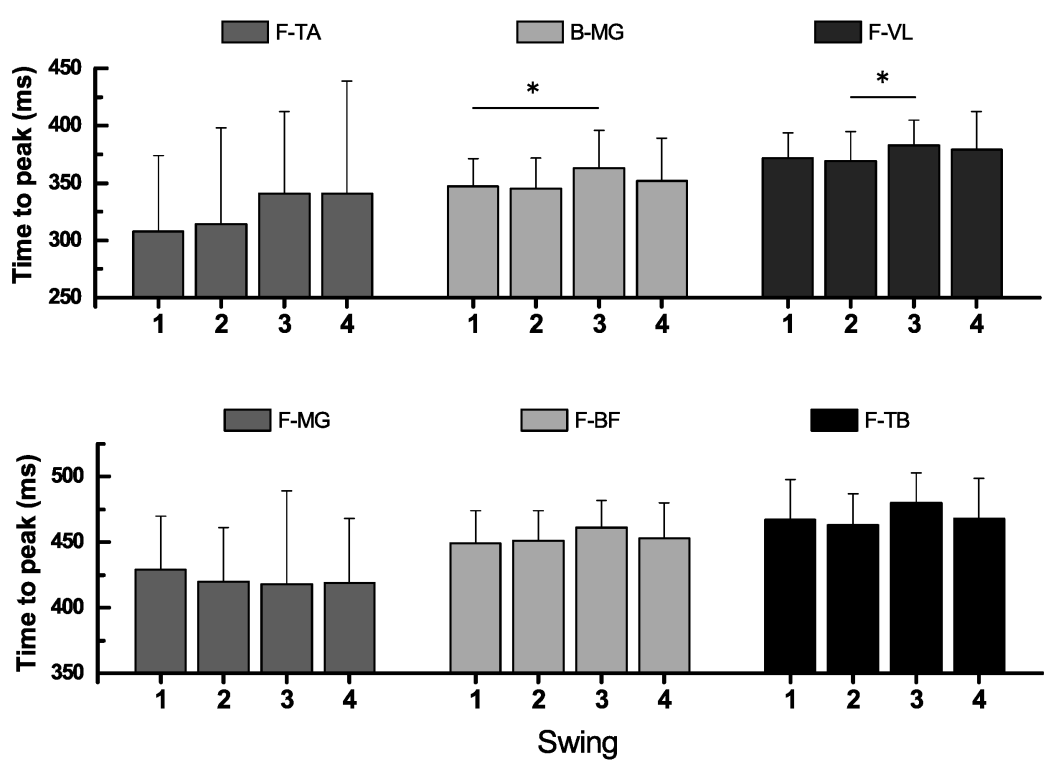

Figure 6 Differences between the 4 swings in terms of time to peak from the target start in the tibialis anterior muscle of the front leg (F-TA), vastus lateralis muscle of the front leg (F-VL), biceps femoris muscle of the front leg $(\mathrm{F}-\mathrm{BF})$, medial gastrocnemius muscle of the front and back legs (F-MG and B-MG, respectively), and triceps brachii of the front arm (F-TB). ${ }^{*} \mathrm{p}<0.05$ 

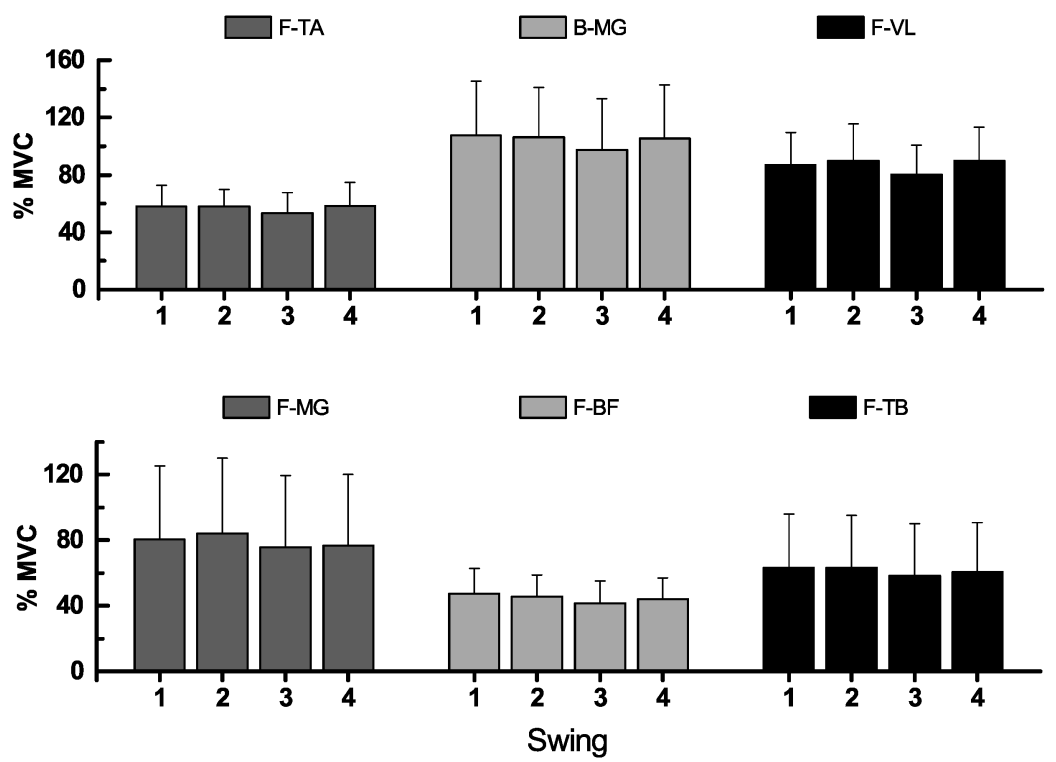

Figure 7 Differences between the 4 swings in terms of maximal muscle activation (\% MVC) of the tibialis anterior muscle of the front leg $(\mathrm{F}-\mathrm{TA})$, vastus lateralis muscle of the front leg $(\mathrm{F}-\mathrm{VL})$, biceps femoris muscle of the front leg $(\mathrm{F}-\mathrm{BF})$, medial gastrocnemius muscle of the front and back legs (F-MG and B-MG, respectively), and triceps brachii of the front arm (F-TB).

$\left.\mathrm{p}=0.021, \eta_{\mathrm{p}}{ }^{2}=0.329\right), 3$ スイング目との間に有 意な違いは認められなかった（B-MG: 1 vs. 3: p $=0.206,2$ vs. $3: p=0.381,3$ vs. $4: p=0.230),(F-$ VL: 1 vs. $3: \mathrm{p}=0.513,2$ vs. $3: \mathrm{p}=0.208,3$ vs. $4: \mathrm{p}$ $=0.082)$. 全ての筋に拈いて, 3 スイング目の平 均值が小さいことから，各スイングで全ての筋の 最大值の平均值を算出した結果, スイング順に $73.9 \pm 12.9 \%, 74.5 \pm 13.4 \%, 67.8 \pm 14.2 \%, 72.5 \pm$ 13.8\% MVC となり，スイング条件で有意な主効 果が認められた $\left(\mathrm{F}(3,24)=8.854, \mathrm{p}<0.001, \eta_{\mathrm{p}}{ }^{2}\right.$ $=0.525)$. 多重比較の結果, 3 スイング目と 2 ス イング目との間には有意な違いが認められた（p =0.040).これらの結果は, バットを短く持つこ とでスイングに関与する筋活動が全体的に低下す ることを示している.

\section{4. 考察}

4.1. バットを短く持ち替えることによる打撃 タイミングへの影響

打撃の一致タイミング誤差はターゲットの到達
時間と打撃ポイントをバットが通過した時間の差 から算出した.ターゲットの到達よりも早くバッ トが打撃ポイントを通過した場合（尚早反応）は - (マイナス) の值, 遅い場合（遅延反応）は + (プラス) の值とした. 本研究では, 4 スイン グ共に CEの平均值がプラスを示したことから (図 2), 平均的に打者はターゲットの到達よりも 遅れてスイングしていた（振り遅れ）と考えられ る. 野球の指導者や選手は, バットを短く持つこ とでスイング時間が短縮されると考えており，野 球の指導書では「速い球に対応して振り遅れない ようにするときにも，短く持てば対応できる.」 とされている(ベースボールマガジン社編, 2007)。をた，バットを短く持つとスイング速度 のバラツキが小さくなることから，打撃のタイミ ングが向上すると示唆されている（DeRenne and Blitzbau, 1990). しかし, 本研究では, 一致タイ ミングの正確性の指標である $\mathrm{AE}$ および変動性を 示す指標である VE は，スイング間で有意な違い は認められず，バットを短く持ち替えても打撃の 時間的な正確性の向上や打撃タイミングのバラッ 
キの減少は示されなかった（図 2).さらに，バ ットを短く持ち替えた 3 スイング目で，タイミ ング䛊差の偏向を示す CE が有意に増加する結果 となった（図 2)。これは，バットを短く持ち替 えたことでターゲットの到達よりも遅れてスイン グする（振り遅れる）傾向が強くなったことを示 すものである．これらのことは，バットを短く持 ち替えることは，打撃の時間的な正確性やバラツ キに顕著な影響を与えるものではないが，標的の 到達に対して振り遅れる傾向を強くする可能性を 示唆するものである.

本研究では, バットを短く持ち替えることによ る打撃タイミングの最終的な遅延（振り遅れ）の 増大だけでなく，スイング動作中の前脚の地面に 対する力発揮と筋活動の時間的な遅延が確認され た（図 3 中，6）。勝又 ・川合（1996）は，ステ ップした前脚が地面を踏みしめることでスイング がなされていると報告している. また，川端・伊 藤（2012）は前脚の床反力のピーク值発揮時間 をスイング開始時点と定義している。したがっ て, 本研究の床反力最大值発揮時間の有意な遅延 はスイング開始局面の遅延を反映するものと示唆 される，さらに，床反力最大值発揮時間よりも前 に出現した F-VL および B-MGの筋活動の最大 值発揮時間も 3 スイング目で有意に遅延したこ とは，スイング開始前の両下肢の準備局面がとも に遅延したことを示すものと考えられる。 また， 2 スイング目と 3 スイング目の $\mathrm{CE}$ の差と床反力 最大值発揮時間の差との間には有意な被検者間の 正の相関関係（図 4) が認められたことから，3 スイング目で振り遅れの程度が大きい被検者は床 反力最大值発揮時間の遅延が大きいことが確認さ れた.さらに, 本研究では, 先行研究 (Escamilla et al., 2009 ; 川端 ·伊藤, 2012 ; 島田ほか, 2008）と同様に，バットを短く持った 3 スイン グ目において，スイング時間に有意な変化は認め られなかった（図 5)。これらの結果は，打撃の 準備局面の遅延がバットを短く持ち替えることに よる振り遅れの増大の主要な原因であると示唆す るものである.

野球競技の打者や監督（コーチ）は，バット
を短く持つことでスイング速度の増加および スイング時間の減少につながると考えている (DeRenne and Blitzbau, 1990). 本実験において も，実験前にアンケートを行った結果，9名中 7 名がバットを短く持つことでスイングが速くなる と回答している. また，9名中 9 名はバットが軽 く感じると回答していることや，8名がバットコ ントロールしやすいと回答している，これらのこ とから，打者はバットを短く持つことによって， 長く持っている時よりも打撃の時間的な余裕を得 ていると考えているかもしれない. 先行研究では, バットを短く持つことでトータルのスイング時間 （前足離地からインパクトをでの時間）が短くな ると報告されている（DeRenne et al., 2010 ; Escamilla et al., 2009). しかし，バットを短く持 つとスイング速度は低下することや（DeRenne and Blitzbau, 1990 ; DeRenne et al., 2010 ; Escamilla et al., 2009 ; 川端 ·伊藤, 2012 ; 渡邊 ほか, 2006), 前脚接地後のスイング時間は有意 に変化しないことが報告されている（Escamilla et al., 2009 ; 川端・伊藤, 2012 ; 島田ほか, 2008，図 5)。したがって，打者や監督（コーチ） が考えるよりも，実際にはバットを短く持つこと による時間的な余裕はそれほど増加しないと考え られる，つまり，バットを短く持った場合の打撃 に抢ける時間的な余裕に抢いて, 打者の認識と現 実との間にズレ（錯覚・過大評価）が生じている 可能性が考えられる．このような，バットを短く 持つことで得られる打撃の時間的余裕の過大評価 が打撃の準備局面の遅延を引き起こし振り遅れの 増大につながったのかもしれない。

本研究では，バットを短く持ち替えた 3 スイ ング目に CE が有意に増加したにも関わらず，ス イングタイミングの早遅についての被検者の主観 にスイング間で有意な違いは認められなかった。 これは,バットを短く持ち替えた 3 スイング目 に抢いて，実際は振り遅れているのにもかかわら ず，他のスイングと同様のタイミングでスイング したと判断した結果であり, 打撃タイミングの遅 れに打者が気付いていないことを示すものと推察 される.この結果は，バットを短く持ち替えるこ 
とによる打者の打撃タイミングの判断能力の低下 を示唆するものかもしれない，今後さらなる研究 は必要であるが，本研究で示されたバットを短く 持ち替えることによる打撃の振り遅れの増大や打 撃タイミングの判断能力の低下の結果は, 1 打席 中にグリップ位置を変えることが打撃パフォーマ ンスの低下につながる可能性を示すものかもしれ ない。

\section{2. グリップ位置が筋活動および床反力の最 大値に与える影響について}

先行研究では, バットを短く持つことによる慣 性モーメントの減少が筋の力発揮の低下につなが ると示唆されている (Escamilla et al., 2009). 本 研究では, 3 スイング目に測定した全ての筋活動 の最大值が低下する傾向が認められ（図 7), BMG 抢よび F-VLに扔いてはスイング条件で有 意な主効果が認められた。野球における打撃動作 は打者によって様々であり, 動員される筋の貢献 度は打者によって異なると考えられることから， 全ての筋活動を平均してスイング間の違いを分析 した結果，バットを短く持ち替えた 3 スイング 目でスイングに関与する筋活動が有意に低下する ことが示された．これは，バットを短く持つこと が筋の力発揮の低下につながるとの示唆 (Escamilla et al.，2009) を支持する結果と言え る.また, 動作前抢よび動作後のダンベルの重さ に関する主観はダンベルの挙上速度や加速度に影 響を与える可能性が示されていることから (Buckingham et al. 2014)，3 スイング目にバッ 卜を軽く感じていることと筋活動量の低下は関連 するものかもしれない.さらに，本研究では， 3 スイング目の床反力最大值の減少は有意ではなか ったが，テニスのフォアハンドストロークのイン パクト時に働く平均の力は床反力から得られたべ クトルと相関すると報告されている（室, 1983).これらのことから, 筋活動量の低下や床 反力值の低下は，バットを短く持った際のスイン グ速度の低下（DeRenne and Blitzbau，1990； DeRenne et al., 2010 ; Escamilla et al., 2009 ; 川端・伊藤， 2012 ; 渡邊ほか，2006）やボール
飛距離の低下（渡邊ほか，2006）に関連するも のかもしれない.

\section{3. 本研究の限界および今後の研究への示唆}

本研究は, 打撃シミュレーターを使用し, ター ゲットの到達時間が全て一定の条件で行われたも のであることが，バットを短く持ち替えることに よる潜在的な影響を顕著に示したものかもしれな い，さらに，本研究ではグリップ位置にかかわら ず全て同じインパクト位置を想定したスイングを 行わせていることから，実際の打撃動作とは異な るものと考えられ，実際の打撃場面においても短 く持ち替えた場合に振り遅れるかどうかは不明で ある、したがって，今後の研究では，実際の試合 のような様々な球速に対して，グリップ位置の変 化が打撃タイミングやインパクト位置に与える影 響を検討することで，短く持ち替えた場合の打撃 タイミングへの影響をさらに明らかにする事がで きよう。また，バットを短く持つと上胴や骨盤の 回転角度が小さくなると報告されている事や (Escamilla et al., 2009), バットの回転半径抢よ び慣性モーメントが小さくなりバットの回転が容 易になると考えられることから，スイングがコン パクトになりバットコントロールがしやすくなる と考えられる。しかし，実際に投球されたボール や本研究で用いられた打撃シミュレーターのよう な動的標的に対して，グリップ位置の変化が空間 的なバットコントロールに与える影響はほとんぞ 検討されていない．動的標的に対して空間的なバ ットコントロールへの影響を明らかにする事は， バットを短く持つことまたは持ち替えることによ る打撃パフォーマンスへの影響を明確にすること につながるだろう。

\section{5. まとめ}

本研究では, バットグリップ位置の変化が打撃 のタイミングに与える影響を，打撃シミュレー ターを用いてターゲット到達に対する一致タイミ ング誤差抢よびスイング中の筋活動と前脚の床反 力の時間的特性から検討を行った。 その結果，バ 
ットを短く持ち替えても絶対䛊差（AE）抢よび 変動誤差（VE）に有意な変化は認められなかっ た. 一方，偏向誤差（CE）はバットを短く持ち 替えたスイングにおいて有意に増加した。 また， 床反力最大值発揮時間および筋活動最大值発揮時 間はバットを短く持ち替えたスイングで有意に遅 延した.さらに，グリップ位置にかかわらずスイ ング時間は一定であった。これらの結果から，本 実験条件では，バットを短く持ち替えてスイング しても時間的な打撃タイミングの向上は認められ ないことが示唆された，さらに，短く持ち替えた 際にスイングの準備動作が遅延することで, スイ ングの振り遅れが増大寸る可能性が示された.

\section{謝辞}

本研究の実施において, 服部樹典氏および米田 壮利氏には多大なご協力をいただきました。ま た，実験参加にご快諾いただいた皆様にも，この 場を借りて感謝の意を記すと共に深く打礼申し上 げます。

本研究の一部は愛知淑徳大学研究助成を受け実 施したものである.

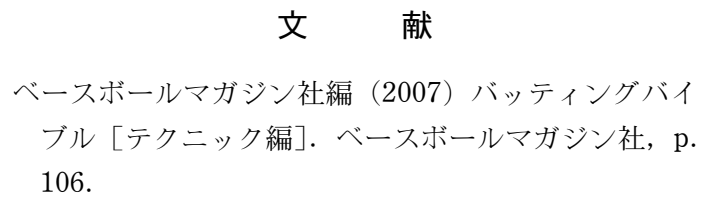

Buckingham, G., Byrne, C.M., Paciocco, J., van Eimeren, L., and Goodale, M.A. (2014) Weightlifting exercise and the size-weight illusion. Attention, Perception, \& Psychophysics, 76 (2): 452-459.

DeRenne, C. and Blitzbau, A. (1990) Why your hitters should choke up. Scholastic Coach, Jan., 59(6): 106107.

DeRenne, C., Morgan, C.F., Escamilla, R.F., and Fleisig, G.S. (2010) A choke-up grip facilitates faster swing and stride times without compromising bat velocity and bat control. The Sport Journal, 13(2).

Escamilla, R.F., Fleisig, G.S., DeRenne, C., Taylor, M.K., Moorman, III, C.T., Imamura, R., Barakatt, E., and Andrews, J.R. (2009) Effects of bat grip on baseball hitting kinematics. J. App. Biomech., 25(3): 203-209.
勝又 宏・川合武司(1996)地面反力からみた異なる投 球速度に対する野球の打撃動作の特性. 体育学研究, 40 (6): 381-398.

Katsumata, H. (2007) A functional modulation for timing a movement: A coordinative structure in baseball hitting. Human Movement Science, 26 (1): 27-47.

川端浩一・伊藤 章 $(2012)$ グリップ位置と投球速度の 違いが野球のバットスイングに及ほす影響. 体育学 研究, 57(2): 557-565.

Kitzman, E.W. (1964) Baseball: Electromyographic study of batting swing. Research Quarterly. American Association for Health, Physical Education and Recreation, 35(2): 166-178.

室 増男(1983)ラケットスイング時の床反力と筋電図 の解析 Jpn. J. Sports Sci. 2(4): 260-268.

Nakamoto, H., Ishii, Y., Ikudome, S., and Ohta, Y. (2012) Kinesthetic aftereffects induced by a weighted tool on movement correction in baseball batting. Human Movement Science, 31(6): 1529-1540.

Ohta, Y., Ishii, Y., Ikudome, S., and Nakamoto, H. (2014) Warm-up with weighted bat and adjustment of upper limb muscle activity in bat swinging under movement correction conditions. Perceptual \& Motor Skills, 118(1): 96-113.

Ohta, Y., Nakamoto, H., Ishii, Y., Ikudome, S., Takahashi, K., and Shima, N. (2015) Muscle activation characteristics of the front leg during baseball swings with timing correction for sudden velocity decrease. PloS one, 10 (4): e0124113.

Schmidt, R. and Lee, T. (2011). Motor control and learning- $5^{\text {th }}$ edition. Human Kinetics, pp. 27-28.

Shaffer, B., Jobe, F.W., Pink, M., and Perry, J. (1993) Baseball batting: An electromyographic study. Clinical orthopaedics and related research, 292: 285-293. 島田一志・田畑広樹 · 川村 卓 (2008) 野球のバッテ イングにおけるバットの握り位置の相違がスイング に与える影響。金沢星稜大学人間科学研究，1(1): 71-74.

渡邊喜満・田中重陽・渡辺 剛・角田直也 (2006)バッ トグリップ位置の違いが打撃能力に及ぼす影響. 東 京体育学研究2005年度報告, 37-40.

$$
\left(\begin{array}{l}
\text { 平成 } 27 \text { 年 } 3 \text { 月 } 30 \text { 日受付 } \\
\text { 平成 } 27 \text { 年 } 7 \text { 月 } 9 \text { 日受理 }
\end{array}\right)
$$

Advance Publication by J-STAGE Published online 2015/8/11 